

\title{
BIJDRAGEN TOT DE TAAL-, LAND- EN VOLKENKUNDE VAN NEDERLANDSCH-INDIË
}

\author{
KONINKLIJK INSTITUUT VOOR DE TAAL-, \\ LAND- EN VOLKENKUNDE VAN \\ NEDERLANDSCH-INDIË
}

\section{DEEL 102}

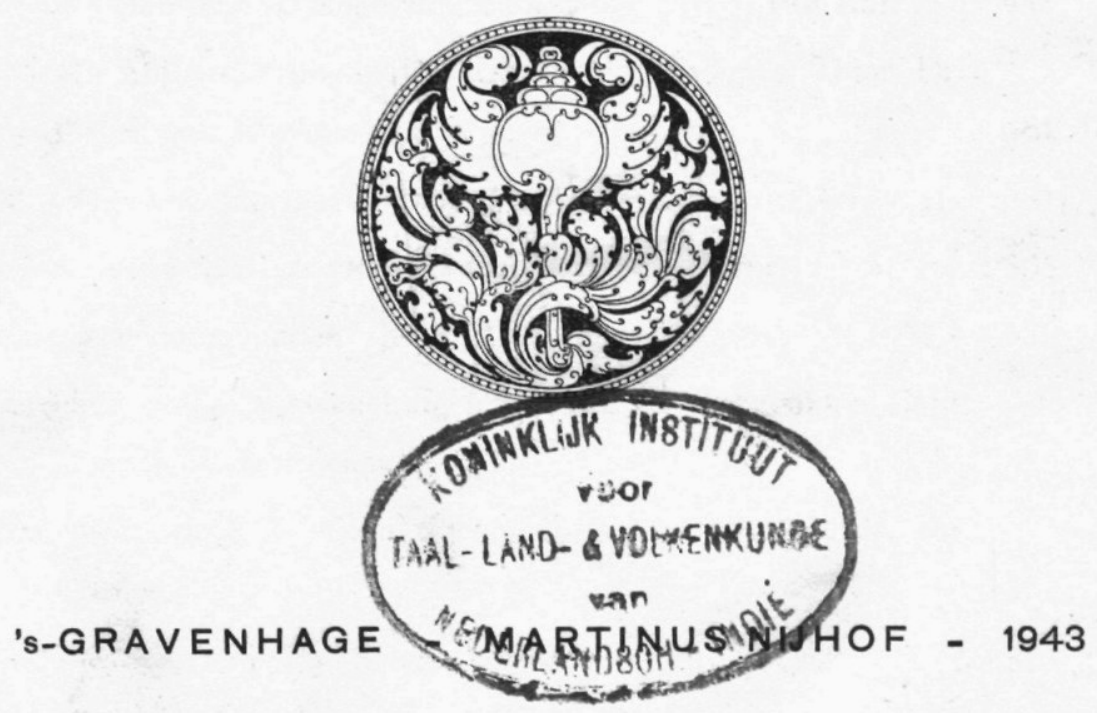




\section{INHOUD}

Bladzijde.

Het rechtsmiddel der revisie voor den Raad van Justitie des kasteels Batavia. Door Mr. J. van Kan . . . . . . . 1

Over de derde persoon meervoud in het Austronesisch. Door

Pater H. Geeroms C.I.C.M. . . . . . . . . . . . 41

De Soendasche Umpak Basa. Door R. A. Kern . . . . . . 81

De z.g. hulppraedicaatswoorden in Maleis en Javaans. Door

J. Gonda . . . . . . . . . . . . . . . . . 95

De Maleische vertelling van den dief-schriftgeleerde en haar

Arabisch origineel. Door Dr. Ph. S. van Ronkel . . . . 105

Correspondentie van Dirk van Hogendorp met zijn broeder

Gijsbert Karel. Door E. du Perron-De Roos . . . . 125

Wortels en grondwoorden in de Austronesische talen. Door

R. A. Kern . 275

Indonesische lasvormen. Door J. Gonda . . . . . . . . 371

Uit de Ceilonsche rechtsgeschiedenis. Door Mr. J. van Kan . . 441

Rānīrī's Maleische geschrift: Exposé der Religies. Door Dr.

Ph. S. van Ronkel . . . . . . . . . . . . . . 461

De Aloreesche dansplaats. Door M. A. Bouman (met 4 foto's) . 481

Indonesische relativa. Door J. Gonda . . . . . . . . 501

Joartan wedergevonden? Door R. A. Kern . . . . . . . 539

Geschiedkundige aanteekeningen betreffende Banggai en Gapi.

Door J. J. Dormeier . . . . . . . . . . 555

Een kind van J. P. Coen terechtgebracht. Door Dr. W. Ph.

Coolhaas . . . . . . . . . . . . 572

Rectificatie. Door Ph. S. van Ronkel . . . . . . . . . 576 
Notulen van de Bestuurs-en Algemeene Vergaderingen en Jaarverslag.

Bladzijde.

Bestuursvergadering van 18 April 1942. . . . . . . . III

Bestuursvergadering van 16 Mei 1942 . . . . . . . v

Bestuursvergadering van 20 Juni $1942 \ldots . . . . . \quad$ vII

Bestuursvergadering van 5 December $1942 \ldots$ IX . . . . IX

Bestuursvergadering van 16 Januari 1943 . . . . X XII

Bestuursvergadering van 20 Februari $1943 \ldots$ xIV

Algemeene Vergadering van 27 Maart 1943 . . . . . xvirI

Jaarverslag . . . . . . . . . . . . . . . . . XxII

Bestuursvergadering van 27 Maart 1943 . . . Xxv

Bestuursvergadering van 17 April 1943....... xxviII

Bestuursvergadering van 15 Mei $1943 \ldots \ldots \ldots$ xxIx

Bestuursvergadering van 26 Juni $1943 \ldots \quad \ldots \quad$ xxx 